\title{
Determinan Perilaku Manajemen Perawatan Diri pada Pasien Diabetes Melitus Tipe 2 di Kota Tangerang Selatan
}

\author{
I da Farida \\ Fakultas IImu Kesehatan, Universitas Islam Negeri Syarif Hidayatullah Jakarta \\ Jl. Kertamukti No.4, Pisangan Ciputat Timur, Kota Tangerang Selatan, Banten 15419 \\ Email: idafa19@gmail.com
}

\begin{abstract}
Abstrak
Diabetes mellitus (DM) adalah penyakit kronis karena gangguan produksi dan atau resistensi insulin yang menyebabkan kadar glukosa darah tinggi yang dapat menyebabkan berbagai komplikasi dengan risiko tinggi penyakit dan kematian. Manajemen perawatan diri adalah salah satu faktor yang menentukan status kesehatan dan kualitas hidup pasien DM tipe 2. Salah satu program pemerintah dalam menangani diabetes mellitus adalah Program Manajemen Penyakit Kronis (Prolanis). Tujuan dari penelitian ini adalah untuk menentukan pengaruh langsung dan tidak langsung dan besarnya pengaruh dukungan keluarga, pendidikan pasien dan melek kesehatan pada manajemen perawatan diri pasien DM tipe 2. Metode yang digunakan dalam penelitian ini adalah pendekatan kuantitatif yang menggunakan desain cross-sectional. Sampel yang digunakan adalah 70 pasien DM dengan peserta Prolanis di Kota Tangerang Selatan. Metode analisis yang digunakan adalah Structural Equation Model (SEM). Temuan penelitian menunjukkan bahwa manajemen perawatan diri pasien DM tipe 2 dipengaruhi oleh faktor dukungan keluarga sebesar $28,92 \%$, faktor pendidikan pasien sebesar 13,13\%, dan faktor literasi kesehatan sebesar 9,5\%. Model struktural dari penelitian ini dapat menjelaskan variabel manajemen perawatan diri sebesar $75,7 \%$. Perawatan kesehatan utama terutama yang bertanggung jawab atas program penyakit tidak menular (PTM) harus lebih meningkatkan partisipasi anggota keluarga pasien dalam kegiatan pendidikan yang berkaitan dengan perawatan diri pasien DM sehingga kualitas manajemen perawatan diri dapat menjadi lebih baik.
\end{abstract}

Kata kunci : Diabetes Mellitus, Dukungan Keluarga, Pendidikan Pasien, Literasi kesehatan, Manajemen Perawatan Diri

\begin{abstract}
Diabetes mellitus (DM) is a chronic disease due to disruption of production and or insulin resistance which causes high blood glucose levels which can cause various complications with a high risk of illness and death. Self-care management is one of the factors that determine the health status and quality of life of type 2 DM patients. One of the government programs in dealing with diabetes mellitus is the Chronic Disease Management Program (Prolanis). The purpose of this study was to determine the direct and indirect effects and magnitude of the influence of family support, patient education and health literacy on self-care management of type 2 DM patients. The method used in this study is a quantitative approach that uses cross-sectional design. The sample used was 70 DM patients with Prolanis participants in South Tangerang City. The analytical method used is Structural Equation Model (SEM). The findings of the study showed that the self-care management of type 2 DM patients was influenced by family support factors of $28.92 \%$, patient education factors by $13.13 \%$, and health literacy factors by $9.5 \%$. The structural model of this study can explain the variables of self-care management by $75.7 \%$. The primary health care especially those in charge of non-communicable diseases programs (PTM) should further enhance the participation of family members of patients in educational activities related to self-care of DM patients so that the quality of self-care management can be better.
\end{abstract}

Keywords : Diabetes Mellitus, Family Support, Patient Education, health literacy, Self Care Management 


\section{Pendahuluan}

Diabetes melitus (DM) telah berkembang menjadi salah satu penyakit tidak menular dengan peningkatan prevalensi yang signifikan hampir diseluruh negara di dunia dengan risiko kematian yang tinggi. Menurut World Health Organization (WHO) Diabetes mellitus yang adalah penyakit kronis yang disebabkan oleh keturunan dan atau kekurangan produksi insulin oleh pankreas, atau disebabkan fungsi insulin yang tidak efektif sehingga meningkatkan konsentrasi glukosa dalam darah, yang akhirnya merusak berbagai sistem tubuh, khususnya pembuluh darah dan saraf. Di seluruh dunia terdapat sekitar 224 juta kasus diabetes dengan 1,5 juta tingkat kematian dan diperkirakan satu dari sebelas penduduk di dunia mempunyai penyakit diabetes. ${ }^{1}$ International Diabetes Federation (IDF) tahun 2013 memperkirakan 382 juta orang di dunia hidup dengan diabetes dan jumlah ini diprediksi meningkat menjadi 592 juta orang pada tahun 2035. Riset kesehatan dasar (Riskesdas) tahun 2013 menyebutkan bahwa proporsi penderita diabetes melitus pada penduduk usia $\geq 15$ tahun sebesar 6,9\% (12.191.564 orang). Dari jumlah ini hanya $30,4 \%$ saja yang terdiagnosis. Sedangkan jumlah penduduk dengan toleransi glukosa terganggu (TGT) dan gula darah puasa (GDP) terganggu masingmasing sebesar $29,9 \%$ (52.830.111 orang) dan $36,6 \%(64.668 .297){ }^{2}$

Kondisi manajemen perawatan diri pasien dapat mempengaruhi status kesehatan dan kualitas hidup di antara populasi yang mengalami masalah kesehatan. Sementara itu manajemen perawatan diri juga dipengaruhi oleh faktorfaktor kontekstual (sumber daya dan nilainilai pada masyarakat), faktor kerentanan yang dapat diubah (kondisi ekonomi, pendidikan, kondisi tempat tinggal) dan tidak dapat diubah (usia, penyakit kronis, jenis kelamin, ras/etnis,) dan sumber intrapersonal (ketegasan, perilaku koping, efikasi diri, dukungan keluarga). Faktorfaktor kerentanan seseorang akan mempengaruhi sumber intra-personal, yang pada gilirannya akan mempengaruhi manajemen perawatan diri baik secara langsung maupun tidak langsung. Kerentanan seseorang dipengaruhi oleh sumber daya yang ada pada dirinya maupun masyarakat dan nilai-nilai yang dianut oleh masyarakat dimana dia tinggal. Manajemen perawatan diri secara teori dapat memprediksi secara langsung bagaimana status kesehatan dan kualitas hidup seseorang. $^{3}$ Salah satu faktor yang mempengaruhi manajemen perawatan diri dan belum banyak diteliti adalah bagaimana pengaruh health literacy (literasi kesehatan) terhadap manajemen perawatan diri khususnya pada pasien diabetes. Health literacy tidak hanya memiliki efek langsung dan tidak langsung terhadap aktivitas perawatan diri pada pasien diabetes tipe 2, tetapi juga berpengaruh terhadap kualitas hidup pasien walaupun pengaruh ini tidak secara langsung. ${ }^{4}$

Pemerintah melalui kementerian kesehatan telah melakukan berbagai program untuk mengatasi dan menurunkan prevalensi diabetes melitus. Salah satu program yang dijalankan adalah Prolanis (Program penagnggulangan penyakit kronis) yang dikhususkan bagi pasien hipertensi dan diabetes mellitus yang mempunyai kartu BPJS. Namun belum banyak diketahui bagaimana efektifitas program ini terhadap perilaku manajemen perawatan diri pasien diabetes dan kualitas hidup pasien sehingga perlu dilakukan penelitian untuk menganalisis sejauh mana program prolanis berdampak pada pasien.

Studi pendahuluan yang dilakukan di beberapa Puskesmas di Kota Tangerang Selatan yaitu Puskesmas Kecamatan Pamulang dan Puskesmas Ciputat terkait manajemen perawatan diri pada pasien diabetes mellitus tipe 2 yang mengikuti program Prolanis diketahui bahwa perilaku manajemen perawatan diri pasien diabetes masih dalam kategori kurang baik. Hasil penelitian pendahuluan menunjukkan bahwa sekitar $80 \%$ pasien masih belum menjalankan standar perawatan diri dari 
aspek perilaku manajemen diet atau asupan makanan, manajemen aktifitas fisik, dan monitoring glukosa darah sendiri.

Hasil penelitian pendahuluan tersebut juga menunjukkan bahwa efektifitas program penanggulangan penyakit tidak menular khususnya diabetes mellitus melalui program Prolanis masih belum berjalan efektif seperti yang diharapkan. Oleh karena itu, peneliti ingin melakukan analisa lebih dalam terkait perilaku manajemen perawatan diri pasien diabetes mellitus tipe 2 dan faktor yang terkait seperti health literacy, edukasi pasien melalui program Prolanis dan dukungan keluarga pasien yang saat ini masih belum banyak diteliti.

\section{Metode}

Penelitian ini merupakan penelitian kuantitatif analitik dengan desain studi cross sectional dimana variabel independen dan dependen diukur pada waktu bersamaan. Jenis penelitian yang gunanya untuk menganalisis hubungan kausal antara variabel-variabel yang diteliti yaitu variabel endogen dan eksogen. Variabel endogen terdiri dari edukasi pasien, health literacy dan dukungan keluarga. Sedangkan variabel eksogen adalah manajemen perawatan diri.

Penelitian dilakukan di beberapa Puskesmas di Kota Tangerang Selatan yang telah menjalankan program Prolanis. Pada masing-masing kecamatan akan dipilih satu Puskesmas sebagai sampel penelitian. Proses penelitian ini akan dilakukan pada bulan Mei - September 2018.

Sampel dalam penelitian ini adalah pasien-pasien diabetes tipe 2 peserta Prolanis yang terdaftar di Puskesmas Kota Tangerang Selatan yang terpilih sebagai sampel. Adapun teknik pengambilan sampel dengan menggunakan Purposive Sample yaitu pengambilan sampel berdasarkan kriteria. Kriteria inklusi yaitu pasien DM tipe 2, usia lebih dari 40 tahun, terdaftar sebagai pasien di Puskesmas yang menjadi sampel penelitian, dan merupakan pasien rawat jalan. Sedangkan kriteria eksklusi dalam penelitian ini adalah pasien DM tipe
1, Diabetes Gestasional, diabetes tipe lain, usia kurang dari 40 tahun, dan tidak bersedia menjadi responden.

Penelitian ini menggunakan alat analisis dengan pendekatan Structural Equation Modelling (SEM), maka penentuan sampel yang representatif menurut Hair et al (1998) adalah jumlah sampel yang diambil minimal adalah 5 kali dari jumlah parameter atau indikator yang digunakan dalam penelitian. Penelitian ini menggunakan 12 indikator yang merupakan acuan dalam pembuatan item-item pertanyaan dalam kuesioner. Indikator dari masing-masing variabel diantaranya adalah untuk dukungan keluarga adalah dukungan informasional, dukungan instrumental, dan dukungan emosional. Indikator edukasi pasien adalah edukasi tentang diet, aktifitas fisik, dan monitoring glukosa darah. Indikator helath literacy adalah fungsional, komunikatif, dan kritis. Indikator manajemen perawatan diri adalah manajemen diet, manajemen aktifitas fisik dan monitoring glukosa darah. Berdasarkan metode tersebut maka jumlah sampel yang diambil dalam penelitian ini adalah $12 * 5=$ 60. Sebagai cadangan sampel, maka jumlah sampel ditambahkan 10 responden untuk menghindari jika ada responden yang tidak sesuai dengan kriteria inkulisi penelitian, sehingga total sampel adalah 70 responden.

Adapun Kota Tangerang Selatan, memiliki 7 kecamatan yang terbagi atas 49 kelurahan dan 5 desa. Dalam penelitian ini agar sampel tersebar secara merata, maka dipilih 1 puskesmas kecamatan pada masing-masing kecamatan dengan jumlah masing-masing puskesmas \pm 10 responden. Adapun nama puskesmas yang menjadi sampel antara lain: Puskesmas Rawa Buntu, Puskesmas Ciputat, Puskesmas Jombang, Puskesmas Ciputat Timur, Puskesmas Pondok Aren, Puskesmas Pamulang dan Puskesmas Setu.

Data dalam penelitian ini bersumber dari data primer. Data primer dikumpulkan berdasarkan jawaban responden pada kuesioner yang diisi langsung oleh pasien. Kuesioner terdiri dari dua bagian, yaitu 
bagian pertama yang berisi data karakteristik responden seperti nama, usia, jenis kelamin, pendidikan, kadar gula darah dan jenis komplikasi diabetes yang dialami. Bagian kedua berisi pertanyaan terkait variabel yang diteliti.

Teknik Analisis Data menggunakan analisis univariate, analisis bivariate dengan menggunakan uji chi square, dan analisis multivariate dengan menggunakan Structural Equation Model (SEM). Alasan menggunakan alat analisis ini dikarenakan adanya beberapa hubungan yang komplek dari beberapa variabel yang diuji dalam penelitian ini, sehingga penggunaan teknik multivariate yang lainnya tidak memadai untuk digunakan.

Analisis SEM dapat untuk memperluas kemampuan menjelaskan dan adanya efisiensi statistik sebagai model yang menguji dengan metode menyeluruh tunggal. Pengujian hipopenelitian dalam penelitian ini menggunakan model persamaan struktural (Structural Equation Model) dengan menggunakan software SmartPLS (Partial Least Structural). Untuk keperluan penolakan atau penerimaan hipopenelitian, digunakan taraf signifikansi konstanta 1,96 .

\section{Hasil}

Tabel 1. Gambaran Karakteristik Umum Responden

\begin{tabular}{llll}
\hline \multicolumn{1}{c}{ Variabel } & \multicolumn{1}{c}{ Kategori } & n & \% \\
\hline Usia & 40-49 Tahun & 16 & 22,9 \\
& 50-59 Tahun & 25 & 35,7 \\
\multirow{5}{*}{ Jenis Kelamin } & >60 Tahun & 29 & 41,4 \\
& Laki-laki & 29 & 41,4 \\
& Perempuan & 41 & 58,6 \\
& SD & 13 & 18,6 \\
& SMP & 13 & 18,6 \\
& SMA & 32 & 45,7 \\
& PT & 12 & 17,1 \\
& Tidak bekerja & 37 & 52,9 \\
& Bekerja & 33 & 47,1 \\
\hline
\end{tabular}

Berdasarkan tabel 1 terlihat bahwa sebagian besar usia penderita diabetes tipe 2 di Tangerang Selatan berada pada usia $\geq 50$ Tabel 2. Analisis Univariat tahun $(77,1 \%)$. Penderita DM tipe 2 dalam penelitian ini lebih banyak pada perempuan $(58,6 \%)$ dibandingkan laki-laki. Pendidikan penderita DM tipe 2 pada penelitian ini paling banyak tingkat SMA (45,7\%). Sedangkan status pekerjaan hamper sama antara yang bekerja $(52,9 \%)$ dan tidak bekerja $(47,1 \%)$.

Berdasarkan data pada tabel 2 terlihat bahwa pada variabel manajemen perawatan diri nilai jawaban responden terkecil adalah 15 dan yang terbesar adalah 89 dengan nilai rata-rata 38,39 . Sedangkan nilai tengah atau median yaitu 34,5 dan nilai jawaban yang terbanyak adalah 15. Pada variabel health literacy, nilai terendah adalah 15 dan tertinggi adalah 74 dengan nilai rata-rata 38,76; nilai tengah 36 dan nilai terbanyak adalah 16. Variabel edukasi pasien memiliki rentang jawaban antara 15 - 30 dengan nilai rata-rata 18,61 dan mempunyai nilai median 15,5 dan nilai modus 15 . Sedangkan untuk variabel Dukungan Keluarga rentang nilai terkecil dan terbesar antara 15 - 75 dengan nilai rata-rata sebesar 44,46 dan nilai median 45,5. Nilai 60 merupakan nilai yang paling sering muncul pada variabel Dukungan Keluarga.

Berdasarkan tabel 3 menyatakan bahwa Dukungan Keluarga mempunyai pengaruh secara langsung dan tidak langsung terhadap manajemen perawatan diri. Hasil uji koefisien parameter antara Dukungan Keluarga terhadap manajemen perawatan diri menunjukan terdapat pengaruh langsung terhadap manajemen perawatan diri sebesar $27,61 \%$, sedangkan untuk pengaruh tidak langsung antara Dukungan Keluarga terhadap manajemen perawatan diri sebesar $1,30 \%$ sehingga total pengaruh langsung dan tidak langsung dari Dukungan Keluarga terhadap manajemen perawatan diri adalah sebesar $28,92 \%$.

Hasil uji koefisien parameter antara edukasi pasien terhadap manajemen perawatan diri menunjukan terdapat pengaruh langsung sebesar 10,66\%, sedangkan untuk pengaruh tidak langsung antara edukasi pasien terhadap manajemen 


\begin{tabular}{|c|c|c|c|c|c|c|c|c|c|c|c|}
\hline \multicolumn{4}{|c|}{ Variabel } & $\mathbf{n}$ & Min & Max & Mean & Median & Mod & Range & $\begin{array}{c}\text { Standar } \\
\text { Deviasi }\end{array}$ \\
\hline \multicolumn{4}{|c|}{ Manajemen Perawatan Diri } & 70 & 15 & 89 & 38,39 & 34,5 & 15 & 74 & 19,529 \\
\hline \multicolumn{4}{|c|}{ Health literacy } & 70 & 15 & 74 & 38,76 & 36 & 16 & 59 & 17,287 \\
\hline \multicolumn{4}{|c|}{ Edukasi pasien } & 70 & 15 & 30 & 18,61 & 15,5 & 15 & 15 & 4,528 \\
\hline $\begin{array}{l}\text { Dukungan } \\
\text { Keluarga }\end{array}$ & 70 & 15 & 75 & 44,46 & & & 60 & 60 & & & 685 \\
\hline
\end{tabular}

Tabel 3. Persentase Pengaruh Antar Variabel Terhadap Variabel Manajemen Perawatan Diri

\begin{tabular}{lccccccc}
\hline Sumber & $\begin{array}{c}\boldsymbol{L V} \\
\text { Correlation }\end{array}$ & $\begin{array}{c}\text { Direct } \\
\boldsymbol{P a t h}\end{array}$ & $\begin{array}{c}\text { Indirect } \\
\boldsymbol{P a t h}\end{array}$ & Total & $\begin{array}{c}\text { Direct } \\
\mathbf{\%}\end{array}$ & $\begin{array}{c}\text { Indirect } \\
\mathbf{\%}\end{array}$ & \%Total \\
\hline $\begin{array}{l}\text { Dukungan } \\
\text { Keluarga }\end{array}$ & 0.621968 & 0.388251 & 0.177981 & 0.6220 & $27.61 \%$ & $1.30 \%$ & $28.92 \%$ \\
$\begin{array}{l}\text { Edukasi } \\
\begin{array}{l}\text { Pasien } \\
\text { Health }\end{array}\end{array}$ & 0.492046 & 0.216711 & 0.078329 & 0.2950 & $10.66 \%$ & $2.47 \%$ & $13.13 \%$ \\
literacy & 0.539436 & 0.176064 & & 0.1761 & $9.50 \%$ & & $9.50 \%$ \\
\hline \multicolumn{2}{r}{} & Total & & & $\mathbf{4 7 . 7 8 \%}$ & $\mathbf{3 . 7 7 \%}$ & $\mathbf{5 1 . 5 5 \%}$ \\
\hline
\end{tabular}

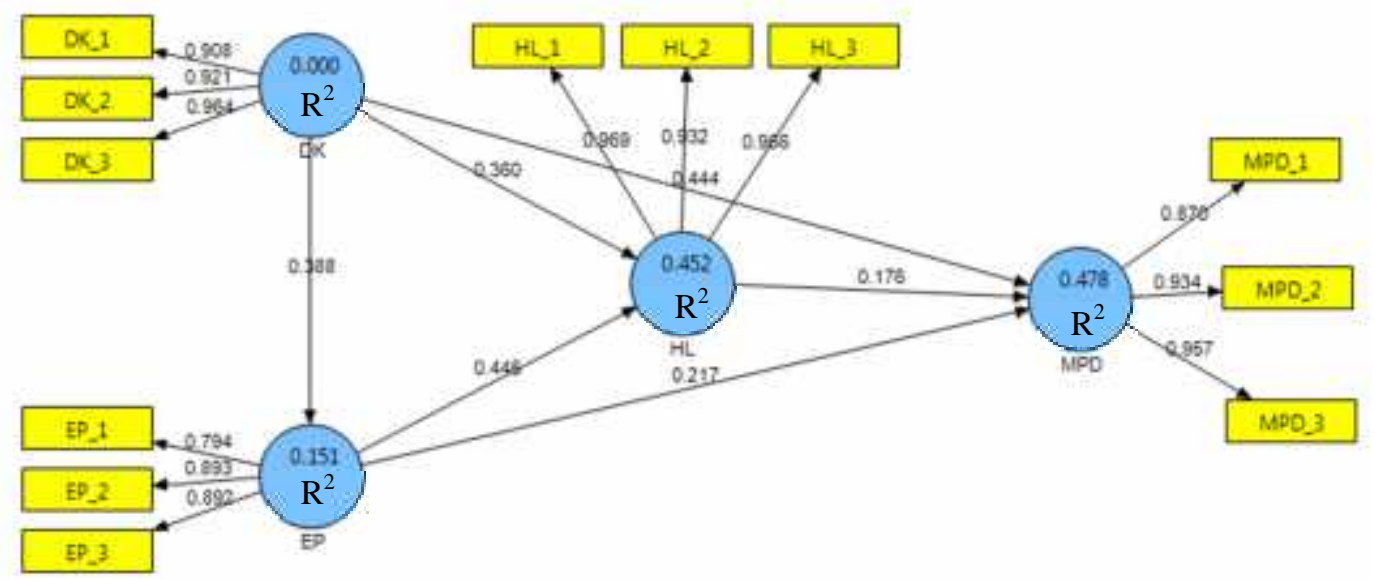

Gambar 1. Hasil Analisis Structural Equation Modeling (SEM)

Ket. $\mathrm{DK}=$ Dukungan Keluarga; $\mathrm{EP}=$ Edukasi Pasien $; \mathrm{HL}=$ Health literacy $; \mathrm{MPD}=$ Manajemen Perawatan Diri

perawatan diri sebesar 2,47\%. Total pengaruh edukasi pasien terhadap manajemen perawatan diri sebesar 13,13\%. Sedangkan variabel health lteracy hanya memiliki hubungan langsung terhadap manajemen perawatan diri sebesar $9,50 \%$.

Dari tabel 3 juga dapat dikatakan bahwa variabel yang paling besar berkontribusi terhadap manajemen perawatan diri adalah Dukungan Keluarga, artinya semakin besar Dukungan Keluargayang diberikan kepada responden maka akan semakin besar juga manajemen perawatan diri pasien DM. Sedangkan secara berturut-turut variabel yang berpengaruh besar sampai yang paling kecil adalah edukasi pasien, dan health literacy.

Berdasarkan nilai $R$-Square $\left(\mathrm{R}^{2}\right)$ dapat dinyatakan bahwa variabel Dukungan Keluarga, edukasi pasien, dan health literacy berkontribusi terhadap manajemen perawatan diri sebesar 0 , 477753 atau $47,75 \%$ dan $52,25 \%$ oleh faktor lain di luar variabel penelitian. Variabel Dukungan Keluarga dan edukasi pasien berkontribusi terhadap health literacy sebesar 0,452186 atau 45,22\% dan 
$54,78 \%$ oleh faktor lain. Variabel Dukungan Keluarga berkontribusi sebesar $0,150739 \quad(15,07 \%)$ terhadap edukasi pasien dan sisanya sebsar $84,93 \%$ ditentukan oleh faktor lainnya (Gambar 1).

\section{Pembahasan \\ Pengaruh Dukungan Keluarga terhadap Manajemen Perawatan Diri pada Pasien DM tipe 2}

Hasil penelitian menunjukkan bahwa variabel dukungan keluarga tidak dipengaruhi oleh karakteristik pasien yang meliputi usia, jenis kelamin, pendidikan dan pekerjaan. Hal ini berarti bahwa pada usia berapapun dukungan keluarga tidak berbeda antara satu responden dengan responden lainnya. Begitu juga dengan jenis kelamin, pendidikan dan pekerjaan tidak akan berbeda.

Nilai path coefficients $(0,443987)$

dan T-statistik (4.884445> 1,96) menunjukkan bahwa dukungan keluarga berpengaruh positif dan signifikan terhadap manajemen perawatan diri pasien DM tipe 2. Dari hasil analisis model struktural menggunakan SEM diperoleh nilai hubungan langsung dan tidak langsung antara dukungan keluarga dengan manajemen perawatan diri pasien DM tipe 2. Pengaruh langsung dukungan keluarga terhadap manajemen perawatan diri pasien DM tipe 2 adalah sebesar 27,61\%, sedangkan untuk pengaruh tidak langsung sebesar $1,30 \%$ sehingga total pengaruh langsung dan tidak langsung dari dukungan keluarga terhadap manajemen perawatan diri pasien DM tipe 2 adalah sebesar $28,92 \%$.

Kendala utama pada penanganan diet DM adalah kejenuhan pasien dalam mengikuti terapi diet yang sangat diperlukan untuk mencapai keberhasilan. Pelaksanaan diet DM sangat dipengaruhi oleh adanya dukungan dari keluarga. Dukungan dapat digambarkan sebagai perasaan memiliki atau keyakinan bahwa seseorang merupakan peserta aktif dalam kegiatan sehari-hari. Perasaan saling terikat dengan orang lain di lingkungan menimbulkan kekuatan dan membantu menurunkan perasaan terisolasi. Jika dukungan keluarga tidak ada maka pasien DM akan tidak patuh dalam pelaksanaan diet, sehingga penyakit DM tidak terkendali dan terjadi komplikasi yaitu penyakit jantung, ginjal, kebutaan, ateroskleorosis, bahkan sebagian tubuh dapat diamputasi. Dan apabila dukungan keluarga baik maka pasien DM akan patuh dalam pelaksanaan diet, sehingga penyakitnya terkendali. ${ }^{5}$

Keluarga mempunyai pengaruh terhadap sikap dan penerimaan pendidikan kesehatan pasien DM. Pasien DM akan bersikap positif untuk mempelajari pengelolaan diabetes melitus apabila keluarga memberikan dukungan dan ikut berpartisipasi dalam pendidikan kesehatan. Sebaliknya apabila keluarga tidak mendukung, acuh tak acuh bahkan menolak pemberian pendidikan kesehatan mengenai pengelolaan diabetes, maka pasien diabetes akan bersikap negatif terhadap pengelolaan diabetes tersebut. ${ }^{6}$ Dukungan keluarga selalu diharapkan agar kondisi semakin membaik karena dengan adanya dukungan keluarga pasien cenderung patuh terhadap diet. Perawat sangat diharapkan untuk memotivasi keluarga pasien agar dapat meningkatkan dukungan terhadap kepatuhan diet pasien DM tipe 2 sehingga nantinya pasien akan menjadi patuh dengan diet yang disarankan oleh petugas kesehatan. Pasien memerlukan dukungan untuk patuh terhadap diet yang harus dijalani. Pasien akan merasakan berupa kualitas kesehatan maupun kualitas hidup yang meningkat pada saat patuh pada diet. Apabila makan dan minum dijaga, akan terhindar dari berbagai macam komplikasi yang hanya akan memperparah dan memperburuk keadaan pasien serta meminimalisir adanya gangguan kesehatan lainnya. ${ }^{6}$

Dukungan keluarga adalah sikap, tindakan dan penerimaan keluarga terhadap penderita yang sakit. Dukungan bisa berasal dari orang lain (orang tua, 
anak, suami, istri atau saudara) yang dekat dengan subjek dimana bentuk dukungan berupa informasi, tingkah laku tertentu atau materi yang dapat menjadikan individu merasa disayangi, diperhatikan dan dicintai. Dukungan keluarga memiliki empat dimensi dukungan yaitu dukungan emosional, dukungan penghargaan, dukungan instrumental dan dukungan informatif. ${ }^{7}$ Dukungan keluarga dapat mempengaruhi kepuasaan seseorang dalam menjalani kehidupan sehari-hari dimana peran keluarga sangat penting dalam setiap aspek perawatan kesehatan keluarga mulai dari strategi - strategi hingga fase rehabilitasi (

Keluarga merupakan bagian terpenting bagi semua orang. Begitu pula bagi penderita diabetes. Disadari atau tidak, saat seseorang mengalami diabetes melitus maka mereka akan mengalami masa-masa sulit. Mereka harus mulai berbenah diri, mulai mengontrol pola makan dan aktifitas. Hal tersebut pasti sangat membutuhkan bantuan dari orang sekitar terutama keluarga, dengan menceritakan kondisi diabetes melitus pada orang terdekat, maka akan membantu dalam kontrol diet dan program pengobatan. Faktor lingkungan dan keluarga merupakan faktor yang berpengaruh dalam menumbuhkan kepatuhan pasien. Dari pernyataan tersebut dapat dilihat bahwa orang terdekat dalam hal ini adalah keluarga mempunyai peranan untuk membantu penderita Diabetes melitus dalam melakukan upaya pencegahan komplikasi Diabetes melitus.

Hasil penelitian yang dilakukan oleh Coffman, ${ }^{9}$ tentang efek dukungan keluarga dan depresi terhadap self efikasi DM tipe 2 di Spanyol menemukan umumnya dukungan yang diterima oleh pasien DM tipe 2 adalah dari keluarga. Coffman menyatakan bahwa keluarga merupakan sumber dukungan yang paling utama. Dukungan keluarga yang dapat diberikan kepada penderita DM tipe 2 bisa dalam bentuk dukungan emosional, penghargaan, instrumental, dan informasi. Dukungan yang diberikan kepada anggota keluarga yang sakit dapat meningkatkan rasa nyaman dan menurunkan stress sehingga dapat meningkatkan kualitas hidup anggota keluarga yang sakit. Dukungan keluarga mampu meningkatkan kualitas hidup bagi penderita $\mathrm{DM}$ tipe 2 dikarenakan dukungan keluarga diberikan dalam bentuk emosional, instrumental, penghargaan dan informasi yang mampu memberikan rasa nyaman dan dapat meningkatkan motivasi pasien dalam menjalani pengobatan dan perawatan diri yang akan mempengaruhi kualitas hidup pasien DM tipe 2 menjadi lebih baik.

Selain itu dukungan keluarga juga dapat berdampak kepada health literacy atau kemampuan pasien dalam mengakses dan mengolah informasi terkait makanan sehingga pasien mampu memutuskan makanan yang akan dikonsumsi. Dukungan social yang berasal dari keluarga mempunyai dampak yang besar terhadap pola diet pasien. Keluarga merupakan pihak yang paling dekat dengan pasien dan sehari-hari berhubungan langsung dengan pasien. Keluarga dapat berperan penting dalam menentukan pola konsumsi makan pasien, menentukan makanan yang boleh dan tidak boleh dimakan, dan membantu mempersiapkan makanan yang sesuai dengan kondisi pasien. Penelitian Ismansyah dan Ernawati, ${ }^{6}$ menyebutkan bahwa terdapat hubungan yang bermakna antara dukungan keluarga dengan kepatuhan diet diabetes pada pasien Diabetes Mellitus tipe II (pv=0,000). Keluarga mempunyai pengaruh terhadap sikap dan penerimaan pendidikan kesehatan pasien Diabetes Melitus. Pasien Diabetes Melitus akan bersikap positif untuk mempelajari pengelolaan diabetes melitus apabila keluarga memberikan dukungan dan ikut berpartisipasi dalam pendidikan kesehatan Diabetes Melitus. 


\section{Pengaruh Edukasi Pasien Terhadap Manajemen Perawatan Diri pada Pasien DM tipe 2}

Hasil penelitian menunjukkan bahwa variabel edukasi pasien tidak dipengaruhi oleh karakteristik pasien yang meliputi usia, jenis kelamin, pendidikan dan pekerjaan yang ditunjukkan dengan hasil uji chi-square> 0,05. Hal ini berarti bahwa pada usia berapapun nilai edukasi pasien tidak berbeda antara satu responden dengan responden lainnya. Begitu juga dengan jenis kelamin, pendidikan dan pekerjaan tidak akan berbeda.

Nilai path coefficients dan T-statistik menunjukkan angka 0,216711 dan $2,937169(>1,96)$ yang berarti bahwa edukasi pasien berpengaruh positif dan signifikan terhadap manajemen perawatan diri pasien DM tipe 2. Dari hasil analisis model struktural menggunakan SEM diperoleh nilai hubungan langsung dan tidak langsung antara edukasi pasien dengan manajemen perawatan diri pasien DM tipe 2. Hasil uji koefisien parameter antara edukasi pasien terhadap manajemen perawatan diri menunjukan terdapat pengaruh langsung sebesar 10,66\%, sedangkan untuk pengaruh tidak langsung antara edukasi pasien terhadap manajemen perawatan diri sebesar $2,47 \%$. Total pengaruh edukasi pasien terhadap manajemen perawatan diri sebesar $13,13 \%$. Selain itu didapatkan juga nilai R Square kontribusi faktor dukungan keluarga terhadap edukasi pasien sebesar 0.150739 $(15,07 \%)$. Walaupun kontribusi ini kecil, tetapi dapat menentukan juga tingkat edukasi pasien DM tipe 2.

Edukasi atau pendidikan pasien adalah proses yang memungkinkan individu untuk membuat keputusan tentang perilaku yang berhubungan dengan kesehatan pribadi mereka. Hal ini bertujuan untuk meningkatkan kesehatan dengan mendorong kepatuhan terhadap pengobatan medis dan mempromosikan gaya hidup sehat. ${ }^{10}$ Edukasi pasien terkait manajemen diri (Diabetes Self Management Education [DSME]) adalah suatu proses yang bertujuan memfasilitasi pengetahuan, keterampilan, dan kemampuan yang diperlukan untuk perawatan diri pasien diabetes. ${ }^{10}$ Pendidikan kesehatan sangat penting dalam pengelolaan DM untuk mendapatkan hasil yang optimal. Pendidikan kesehatan pada pasien DM sebaiknya dilakukan oleh semua pihak yang terkait dalam pengelolaan DM, seperti dokter, perawat, ahli gizi. Pendidikan kesehatan pencegahan primer harus diberikan kepada kelompok masyarakat resiko tinggi. Pendidikan kesehatan sekunder diberikan kepada kelompok pasien DM. Sedangkan pendidikan kesehatan untuk pencegahan tersier diberikan kepada pasien yang sudah mengidap DM dengan penyulit menahun Edukasi dengan tujuan promosi hidup sehat, perlu selalu dilakukan sebagai bagian dari upaya pencegahan dan merupakan bagian yang sangat penting dari pengelolaan DM secara holistik.

Penelitian Murray \& Shahc, ${ }^{11}$ juga sejalan dengan hasil penelitian tersebut. Penelitian ini menggunakan kohort pada warga Ontario, Kanada dengan diagnosis diabetes berusia $\searrow 65$ tahun dilakukan dengan menggunakan basis data administrasi. Kehadiran pada program pendidikan diabetes diidentifikasi menggunakan registry kunjungan ke semua program pendidikan diabetes. Hasil penelitian ini menyebutkan bahwa Pasien yang mengikuti program pendidikan diabetes lebih rutin mengonsumsi statin (70,6\%) dibandingkan pasien yang tidak hadir $(69,4 \%, \mathrm{p}<0,0001)$. Program edukasi diabetes dikaitkan dengan pemanfaatan yang lebih besar dari obat penurun glukosa $(83,7 \%$ vs $82,0 \%$, p <0,0001), obat antihipertensi $(90,2 \%$ vs $89,7 \%, \quad$ p $<0,0001$ ), angiotensin converting enzyme inhibitor / angiotensin receptor blockers $(79,8 \%$ vs $78,9 \%$ p <0,0001), dan glukosa monitoring strip $(82,2 \%$ vs $65,6 \%$, p $<0,0001)$. Semakin sering pasien mengikuti program edukasi diabetes, maka pengetahuan, keterampilan serta 
kemampuannya dalam melakukan manajemen perawatan diri akan lebih baik dan akan meningkatkan kualitas perawatan diri pasien.

Pada penelitian ini, berdasarkan informasi yang didapat dari Puskesmas Kota Tangerang Selatan diketahui bahwa kegiatan edukasi yang dilakukan meliputi penyuluhan terkait diabetes yang jadwal kegiatannya tidak tentu. Program rutin Puskesmas salah satunya adalah kegiatan Posbindu yang dilakukan setiap bulan. Kegiatan Posbindu merupakan kegiatan khusus bagi lansia yang kegiatan utamanya meliputi pemeriksaan kesehatan bagi lansia dan penyuluhan kesehatan. Selain itu khusus bagi pasien yang mempunyai kartu BPJS dapat mengikuti program khusus bagi pasien dengan penyakit kronis atau disebut Prolanis (Program Penanganan penyakit kronis). Program ini dikhususkan bagi pasien BPJS dengan penyakit kronis seperti hipertensi dan diabetes mellitus. Pada program prolanis pasien akan mendapatkan pemeriksaan kesehatan terkait penyakitnya dan penyuluhan yang lebih lengkap terkait penyakit. Selain itu ada kegiatan senam rutin yang merupakan kegiatan aktivitas fisik bagi pasien. Namun, tidak semua pasien diabetes di Kota Tangerang Selatan bisa memanfaatkan program ini karena tidak mempunyai kartu BPJS.

Diabetes merupakan penyakit yang kompleks dan berat dengan berbagai komplikasi yang dapat menyebabkan kematian. Pasien diabetes membutuhkan orang lain untuk membuat keputusan terhadap manajemen harian mengenai makanan, aktivitas fisik, dan obat-obatan. Hal ini juga mengharuskan bahwa pasien diabetes tersebut memiliki kemampuan dalam sejumlah keterampilan manajemen diri. Agar pasien diabetes dapat mempelajari tentang keterampilan yang diperlukan untuk manajemen perawatan diri, maka edukasi diabetes sangat penting dalam meletakkan dasar bagi dukungan yang berkelanjutan dalam perawatan diri pasien selama menjalani pendidikan.
Sangat penting bagi pusat pelayanan kesehatan, khususnya Puskesmas untuk memberikan perawatan yang berkualitas, memfasilitasi pasien untuk mengikuti program edukasi rutin seperti Prolanis, dan mengatasi hambatan yang mungkin dialami pasien serta dan mengeksplorasi sumber daya yang memungkinkan pasien dapat mengikuti edukasi secata berkelanjutan.

Edukasi pasien dapat mempengaruhi health literacy pasien karena dengan edukasi yang tinggi, maka kemampuan pasien dalam menentukan pola diet yang sehat dan sesuai dengan penyakitnya semakin baik juga. Penerapan edukasi dengan pendekatan prinsip DSME dapat menimbulkan kemampuan manajemen diri yang baik sehingga dapat meningkatkan perilaku kepatuhan manajemen diri pada penderita DM tipe 2 yang berdampak kepada peningkatan kualitas hidupnya.

\section{Pengaruh Health literacy Terhadap Manajemen Perawatan Diri pada Pasien DM tipe 2}

Hasil penelitian menunjukkan bahwa variabel health literacy tidak dipengaruhi oleh karakteristik pasien yang meliputi usia, jenis kelamin, pendidikan dan pekerjaan. Hal ini berarti bahwa dengan perbedaan karkteristik tersebut health literacy tidak berbeda antara satu responden dengan responden lainnya.

Dari nilai path coefficients sebesar 0,176064 dan T-statistik sebesar 2.098385 $(>1,96)$ dapat dikatakan bahwa variabel health literacy berpengaruh positif dan signifikan terhadap manajemen perawatan diri pasien DM tipe 2. Health literacy hanya memiliki hubungan langsung dengan manajemen perawatan diri sebesar 9,59\%. Selain itu health literacy juga dipengaruhi oleh faktor lain dalam penelitian ini yaitu faktor dukungan keluarga sebesar19,20\%, faktor edukasi pasien sebesar $26,02 \%$ dan sisanya $54,78 \%$ dipengaruhi oleh faktor lain yang tidak diteliti dalam penelitian ini.

Health literacy adalah istilah yang 
digunakan untuk menggambarkan kemampuan seseorang untuk menggunakan infromasi kesehatan yang diperolehnya untuk membuat keputusan terkait penggunaan pelayanan kesehatan. Health literacy didefinisikan sebagai sebagai kemampuan untuk mengakses, memahami, dan menggunakan informasi kesehatan, dalam rangka meningkatkan dan memelihara kesehatan yang optimal. ${ }^{12}$ Health literacy mengacu pada karakteristik individu dan sumber daya sosial yang diperlukan bagi individu dan masyarakat untuk mengakses, memahami, menilai dan menggunakan informasi dan layanan untuk membuat keputusan terkait kesehatan termasuk kapasitas untuk berkomunikasi, menegaskan dan memberlakukan keputusan-keputusan tersebut. ${ }^{1}$

Health literacy menyatukan banyak konsep yang berhubungan dengan apa yang orang-orang dan masyarakat butuhkan dalam membuat keputusan yang efektif terkait dengan kesehatan mereka, keluarga dan masyarakat mereka. Keputusan yang berhubungan dengan kesehatan tersebut dapat terkait tentang kesehatan dirinya sendiri, kesehatan orang lain, atau kesehatan masyarakat. Keputusan ini dapat dilakukan baik oleh sekelompok orang (misalnya, keluarga atau masyarakat) atau individu. Health literacy individu dan komunitas berpengaruh (dan dipengaruhi oleh) perilaku kesehatan dan karakteristik masyarakat dan sistem kesehatan. Oleh karena itu, dalam berbagai kondisi yang berbeda yang mempengaruhi seseorang, maka kemampuan health literacy dapat berbeda.

Individu dan masyarakat memiliki kekuatan literasi kesehatan yang berbeda dan keterbatasan yang mempengaruhi seberapa efektif mereka terlibat dengan informasi dan layanan kesehatan. Sistem kesehatan dan layanan sosial juga dapat memberikan kekuatan dan keterbatasan dalam respon mereka terhadap kemampuan literasi kesehatan masyarakat yang mereka layani. Kemampuan merespon literasi kesehatan menggambarkan cara di mana layanan, lingkungan dan produk yang membuat informasi kesehatan dan mendukung ketersediaan dan akses oleh orang-orang dengan kekuatan literasi kesehatan yang berbeda dan terbatas.

Respon yang efektif terhadap masalah literasi kesehatan dapat meningkatkan dampak kesehatan dan mengurangi kesenjangan kesehatan. Mempertimbangkan health literacy masyarakat dalam semua kebijakan akan mendorong pengembangan layanan, lingkungan dan produk yang meningkatkan kemampuan individu dan masyarakat untuk terlibat aktif dalam pencairan informasi yang dapat mendukung kesehatannya dan dapat pula meningkatkan ketersediaan dan aksesibilitas informasi dan dukungan. Tindakan untuk mengatasi masalah health literacy akan memperkuat masyarakat dan mengurangi kesenjangan sosial dan kesehatan.

Penelitian ini didukung oleh penelitian sebelumnya oleh Lee, et $\mathrm{al}^{4}{ }^{4}$ yang menyatakan bahwa Health literacy mempunyai efek langsung dan tidak langsung terhadap aktivitas perawatan diri, dan efek tidak langsung terhadap kualitas hidup. Berdasarkan nilai R2, model akhir menyumbang $20,0 \%$ dari varians dalam efikasi diri, $61,0 \%$ dari varians dalam aktivitas perawatan diri, dan $16,0 \%$ dari varians dalam HRQOL (Health Related Quality of Life). Selain itu pasien dengan tingkat literasi kesehatan yang tinggi, cenderung akan memiliki pengetahuan yang lebih terkait diabetes

Health literacy dalam penelitian ini juga dipengaruhi oleh faktor dukungan keluarga $(19,20 \%)$ dan edukasi pasien $(26,20 \%)$. Hasil ini semakin menguatkan bahwa edukasi pasien berperan penting dalam meningkatkan kemampuan literasi pasien dalam kaitannya dengan penyakit diabetes yang sedang dialami. Sebagian besar pasien DM tipe 2 merupakan pasien dengan usia $>50$ tahun sehingga memiliki keterbatasan dalam menyiapkan dan mengatur makanan yang akan dikonsumsi. Oleh karena itu dukungan dari keluarga 
sangat penting bagi pasien. Keluarga dapat berperan signifikan dalam menentukan pola makanan pasien diabetes sehingga dapat mencegah kenaikan glukosa darah yang sebagian besar disebabkan karena diet yang tidak sehat. Selain itu pendidikan dan edukasi pasien oleh tenaga kesehatan terkait pola makan, makanan yang boleh dan tidak boleh dikonsumsi, jadwal makan, dan jumlah makanan yang boleh dikonsumsi penting dilakukan agar pasien dapat memiliki keterampilan dan efikasi diri terkait diet yang tinggi agar mampu melakukan aktivitas perawatan diri yang baik.

\section{Kesimpulan}

Hasil peneltian ini menunjukkan bahwa keluarga mempunyai peranan penting dalam menentukan baik atau buruk manajemen perawatan diri pasien diabetes melitus dalam hal pola makan (diet), pengobatan, aktivitas fisik, dan pengukuran gula darah. Oleh karena itu, perlu perhatian lebih besar terhadap peran keluarga dan melibatkan keluarga dalam setiap aktivitas pasien. Selain itu faktor literasi kesehatan dan edukasi pasien oleh Puskesmas dalam program prolanis juga harus lebih ditingkatkan karena terbukti berkontribusi cukup besar dalam menentukan manajemen perawatan diri pasien diabetes.

\section{Daftar Pustaka}

1. World Health Organization. Diabetes fact-sheet. www.who.int-fact sheet.html. REVIEW NOVEMBER 2016 http://www.who.int/mediacentre/factsheets/fs31 2/en/

2. Kementerian Kesehatan RI. PUSDATIN. Situasi dan Analisis Diabetes; 2014.

3. Jenerette CM. \& Phillips RCS. Self-Care Management, and Health Outcomes in Older and., 7(3), pp.1-24; 2006.

4. Lee E.-H., Lee, Y.W. \& Moon, S.H. A Structural Equation Model Linking Health Literacy to Self-efficacy, Self-care Activities, and Health-related Quality of Life in Patients with Type 2 Diabetes. Asian Nursing Research, 10(1), pp.82-87; 2016. Available at: http://www.sciencedirect.com/science/article/pii /S1976131716000153.
5. Susanti ML. \& Sulistyarini T., Jurnal STIKES Volume 6, No. 1, Juli 2013. , 6(1); 2013.

6. Ismansyah dan Ernawati. Hubungan Dukungan Keluarga Dengan Kepatuhan Diet Diabetes Melitus Pada Pasien Diabetes Melitus Tipe II. Jurnal Husada Mahakam. Volume III No. 8, November 2014, hal .389-442; 2014.

7. Friedman, Marilyn M. Buku ajar keperawatan keluarga: Riset, Teori dan Praktek. Jakarta : EGC; 2010.

8. Tamara E. et al., Hidup Pasien Diabetes Mellitus Tipe Ii Di Rsud Arifin Achmad Provinsi Riau. , pp.1-7.

9. Coffman MJ. Effect of tangible social support and depresiaon on diabetes self-efficacy. Journal of gerontological nursing, 34 (4), 32-39; 2010.

10. Powers MA. et al., Diabetes Self-management Education and Support in Type 2 Diabetes. , pp.1-14; 2015.

11. Murray CM \& Shah BR. Diabetes selfmanagement education improves medication utilization and retinopathy screening. Primary Care Diabetes, pp.1-7; 2015. Available at: http://dx.doi.org/10.1016/j.pcd.2015.10.007.

12. Velardo S. The Nuances of Health Literacy, Nutrition Literacy, and Food Literacy. Journal of Nutrition Education and Behavior, 47(4), pp.385-389; 2015. Available at: http://dx.doi.org/10.1016/j.jneb.2015.04.328 